\title{
Leptin Attenuates Acute Food Deprivation-Induced Relapse to Heroin Seeking
}

\author{
Uri Shalev, Jasmine Yap, and Yavin Shaham \\ Behavioral Neuroscience Branch, National Institute on Drug Abuse/Intramural Research Program, Baltimore, \\ Maryland 21224
}

Studies in rats have shown that intermittent footshock stress reinstates drug seeking after prolonged drug-free periods. Recently, we found that another environmental stressor, acute $1 \mathrm{~d}$ food deprivation, potently reinstates heroin seeking in rats. Here we report that this effect of food deprivation can be blocked by leptin, a hormone involved in the regulation of energy balance and food intake. Rats were trained to selfadminister heroin (0.05-0.1 mg/kg, i.v., per infusion, three $3 \mathrm{hr}$ sessions per day) for 8-10 d. The heroin-reinforced behavior was then extinguished for 10-13 d, during which lever presses had no reinforced consequences. Subsequently, rats were tested for reinstatement after $1 \mathrm{~d}$ of food deprivation (experiment 1) or exposure to intermittent footshock (15 min, $0.6 \mathrm{~mA}$ )

Studies in humans report that stressful life events are associated with craving and relapse to drugs (Shiffman and Wills, 1985; Sinha et al., 1999). In laboratory animals, the effect of exposure to stress on relapse to drug seeking can be studied in a reinstatement model (Stewart and de Wit, 1987) in which animals trained to self-administer drugs are exposed to acute stress after extinction of the drug-reinforced behavior. Studies in rats have shown that intermittent footshock stress reliably reinstates heroin (Shaham and Stewart, 1995), cocaine (Erb et al., 1996), nicotine (Buczek et al., 1999), and alcohol (Lê et al., 1998) seeking, an effect mediated by central noradrenaline (NA) and corticotropin-releasing factor (CRF) systems (Shaham et al., 2000b).

Recently, we found that another environmental stressor, acute $1 \mathrm{~d}$ food deprivation, reliably reinstates heroin seeking (Shalev et al., 2000). These data extend previous reports on the effect of acute $1 \mathrm{~d}$ food deprivation on sensitivity to lateral hypothalamus brain stimulation reward (BSR) (Carr and Simon, 1984) and on the effect of acute $1 \mathrm{~d}$ food restriction ( $~ 30-40 \%$ of free-feeding) on the self-administration of psychostimulant and opioid drugs (Carroll, 1999) and reinstatement of cocaine seeking (Carroll, 1985). Our data also are in agreement with reports on the effect of chronic food restriction (several weeks of $30-40 \%$ of freefeeding) on sensitivity to BSR (Carr, 1996), on drug-induced lowering of threshold for BSR (Cabeza de Vaca and Carr, 1998),

\footnotetext{
Received Oct. 18, 2000; revised Nov. 20, 2000; accepted Nov. 29, 2000.

Copyright (C) 2001 Society for Neuroscience $\quad 0270-6474 / 01 / 210001-\bullet \$ 15.00 / 0$

This work was supported by the National Institute on Drug Abuse, Intramural Research Program. We thank Drs. Barbara Woodside, Roy Wise, and Jane Stewart for their helpful comments.

Correspondence should be addressed to Dr. Yavin Shaham, Behavioral Neuroscience Branch, Intramural Research Program/National Institute on Drug Abuse/National Institutes of Health, 5500 Nathan Shock Drive, Baltimore, MD 21224. E-mail: yshaham@intra.nida.nih.gov.
}

and heroin priming injections $(0.25 \mathrm{mg} / \mathrm{kg}$, s.c.) (experiment 2). Acute food deprivation reinstated heroin seeking, an effect that was attenuated by leptin (2 or $4 \mu \mathrm{g} / \mathrm{rat}$, i.c.v.; two infusions, given $21 \mathrm{hr}$ and 20-30 min before the start of the test sessions). In contrast, leptin had no effect on reinstatement of heroin seeking induced by intermittent footshock or priming injections of heroin. These data indicate that food deprivation can provoke relapse to heroin seeking via a leptin-dependent mechanism, which is not involved in relapse induced by footshock stress or reexposure to heroin.

Key words: extinction; food deprivation; heroin self-administration; leptin; reinstatement; relapse; stress

and on drug self-administration (Carroll, 1999) and conditioned place preference (Gaiardi et al., 1987; Cabib et al., 2000).

Despite the robust effect of food deprivation or restriction on drug self-reinforced behavior, little is known on the neuronal substrates underlying this effect (Carroll, 1999; Cabib et al., 2000). It has been suggested that hormonal and neuronal systems that are altered by the negative energy balance induced by food restriction act on brain reward circuits to increase sensitivity to the rewarding effects of drugs of abuse and BSR (Carr, 1996). In agreement with this idea, it was found recently that intracerebroventricular infusions of leptin reverse chronic food restrictioninduced sensitization of lateral hypothalamus BSR (Fulton et al., 2000). Leptin, the product of the obese $(o b)$ gene, is secreted by peripheral adipocytes, its plasma levels reflect the size of the fat mass, and the hormone is thought to be involved in long-term energy balance (Friedman and Halaas, 1998). Central infusions of leptin into the ventricles or into specific hypothalamic nuclei (arcuate nucleus, ventromedial hypothalamus, and lateral hypothalamus) decrease food intake and increase energy use, indicating that the actions of leptin are centrally mediated (Ahima et al., 2000).

This article is published in The Journal of Neuroscience, Rapid Communications Section, which publishes brief, peerreviewed papers online, not in print. Rapid Communications are posted online approximately one month earlier than they would appear if printed. They are listed in the Table of Contents of the next open issue of JNeurosci. Cite this article as: JNeurosci, 2001, 21:RC129 (1-5). The publication date is the date of posting online at www.jneurosci.org.

http://www.jneurosci.org/cgi/content/full/4980 
Table 1. Lever-pressing behavior during the training and extinction phases

\begin{tabular}{|c|c|c|c|c|c|c|c|}
\hline & \multirow[b]{2}{*}{$\begin{array}{l}\text { Heroin } \\
\text { infusions }\end{array}$} & \multicolumn{2}{|c|}{ Last Day Training } & \multicolumn{2}{|c|}{ Day 1 Extinction } & \multicolumn{2}{|c|}{ Last Day Extinction } \\
\hline & & $\begin{array}{l}\text { Total } \\
\text { responses, } \\
\text { active lever }\end{array}$ & $\begin{array}{l}\text { Responses, } \\
\text { inactive } \\
\text { lever }\end{array}$ & $\begin{array}{l}\text { Total } \\
\text { responses, } \\
\text { active lever }\end{array}$ & $\begin{array}{l}\text { Responses, } \\
\text { inactive } \\
\text { lever }\end{array}$ & $\begin{array}{l}\text { Total } \\
\text { responses, } \\
\text { active lever }\end{array}$ & $\begin{array}{l}\text { Responses, } \\
\text { inactive } \\
\text { lever }\end{array}$ \\
\hline Exp. 1 & $18.9 \pm 1.8$ & $48.4 \pm 5.5$ & $2.2 \pm 0.5$ & $142.2 \pm 18.4$ & $4.0 \pm 1.1$ & $14.1 \pm 1.6$ & $3.8 \pm 0.8$ \\
\hline Exp. 2 & $20.0 \pm 2.0$ & $72.9 \pm 10.3$ & $3.8 \pm 1.4$ & $122.8 \pm 21.4$ & $3.2 \pm 0.8$ & $14.0 \pm 1.2$ & $2.6 \pm 0.9$ \\
\hline
\end{tabular}

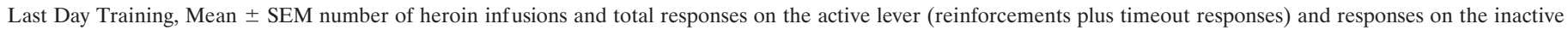

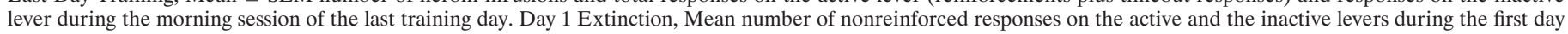
of extinction. Last Day Extinction, Mean number of nonreinforced responses on the active and the inactive levers during the last day of extinction.

Here we report that intracerebroventricular inf usions of leptin attenuate reinstatement of heroin seeking induced by acute $1 \mathrm{~d}$ food deprivation. To further study the role of leptin in reinstatement of heroin seeking, we also determined the effect of the hormone on reinstatement induced by intermittent footshock stress and heroin priming injections. Leptin had no effect on reinstatement of heroin seeking induced by these events, suggesting that the hormone is selectively involved in reinstatement induced by acute food deprivation.

\section{MATERIALS AND METHODS}

Subjects. Sixty-four male Long-Evans rats (350-400 gm; Charles River, Raleigh, NC) were used. Rats were transferred to the self-administration boxes 5-7 d after surgery, where they were chronically housed under a reversed $12 \mathrm{hr}$ light/dark cycle (lights on 10:00 P.M.). Water and food were available ad libitum, except when food deprivation conditions were applied (see below). The experimental chambers had two levers located $9 \mathrm{~cm}$ above the floor, but only one lever (an active, retractable lever) activated the infusion pump (Razel Scientific Instruments, Stamford, $\mathrm{CT}$ ). Presses on the other lever (an inactive, stationary, nonretractable lever) were recorded but did not activate the infusion pump. The grid floors of the chambers were connected to electric shock generators (Med Associates, Georgia, VT). The experimental procedures followed the Principles of Laboratory Animal Care (National Institutes of Health publication number $86-23,1996)$ and were approved by the local Animal Care and Use Committee.

Surgery. Rats were implanted under anesthesia (a mixture of xylaxine plus ketamine, 10 plus $100 \mathrm{mg} / \mathrm{kg}$, i.p.) with intravenous SILASTIC catheters (Dow Corning, Midland, MI) into the right jugular vein as described previously (Shalev et al., 2000). For each rat, a guide cannula (23 gauge; Plastics One, Roanoke, VA) was also implanted during the intravenous surgery. The cannula was aimed $2 \mathrm{~mm}$ above one of the lateral ventricles: $-0.9 \mathrm{~mm}$ posterior, $1.4 \mathrm{~mm}$ lateral, and $2.0 \mathrm{~mm}$ ventral to bregma (Paxinos and Watson, 1998). After surgery, the catheters were flushed every $24-48 \mathrm{hr}$ with sterile saline $(0.05 \mathrm{ml})$. At the end of the experiments, cannula placement was verified by demonstrating a shortlatency $(<60 \mathrm{sec})$ drinking response to angiotensin II (100 ng, i.c.v.).

Procedure. The experiments included three phases: self-administration training, extinction training, and tests for reinstatement. Eighteen of the 64 subjects were excluded because of poor health, loss of head cap, catheter blockade, or misplaced cannulas. The numbers of animals mentioned below refer only to those included in the analyses. Training was conducted for $8-10 \mathrm{~d}$, three $3 \mathrm{hr}$ sessions per day that were separated by $3 \mathrm{hr}$. The first session of each day started at the beginning of the dark cycle. Each response on the active lever resulted in the delivery of 0.1 $\mathrm{mg} / \mathrm{kg}$ (first 4-6 d) or $0.05 \mathrm{mg} / \mathrm{kg}$ (last 3-4 d) of heroin (diacetylmorphine $\mathrm{HCl}$; National Institute on Drug Abuse, Baltimore, MD). During the timeout period, lever presses were not reinforced, and a cue light located above the active lever was turned on. Each session began with the introduction of the active lever into the chamber and the illumination of the white cue light above this lever for $30 \mathrm{sec}$. A red house light was turned on for the entire session. At the end of each session, the house light was turned off and the active lever was retracted. During the extinction phase, the experimental conditions were identical to those of the training phase, with the exception that the heroin syringes were removed. For the first $7 \mathrm{~d}$, rats were given three $3 \mathrm{hr}$ extinction sessions per day. Subsequently, the number of sessions was reduced to one $3 \mathrm{hr}$ session per day, and rats were given 3-6 daily extinction sessions until they reached the extinction criterion of 20 responses or less on the previously active lever. At this point, tests for reinstatement started.

Experiment 1: effect of leptin on food deprivation-induced reinstatement. Twenty-five rats were randomly assigned to one of three leptin dose conditions: vehicle, $2 \mu \mathrm{g} / \mathrm{rat}$, or $4 \mu \mathrm{g} / \mathrm{rat}$ ( $n=8-9$ per dose). Recombinant murine leptin was obtained from Peprotech (Roanoke, VA), and the doses of the hormone used were based on previous reports (Widdowson et al., 1997; Fulton et al., 2000). Food deprivation was accomplished by removing the food hoppers from the chambers for $21 \mathrm{hr}$ before the $3 \mathrm{hr}$ test sessions. The food hoppers were brought back to the chambers at the end of the test sessions. Leptin or vehicle (distilled water; $2 \mu \mathrm{l}$ ) was inf used via a $10 \mu$ l Hamilton syringe, connected with PE-50 tubing to a 30 gauge injector (Plastics One) that was lowered $2 \mathrm{~mm}$ below the cannula tip. Leptin is involved in the long-term regulation of energy balance (Friedman and Halaas, 1998), and the hormone levels are decreased as early as $4 \mathrm{hr}$ after the onset of food deprivation in rats (Dallman et al., 1999). Therefore, drug-vehicle infusions were given twice: $21 \mathrm{hr}$ and 20-30 min before the start of the test sessions. The two inf usions were given to activate the leptin system in the brain at the onset of the food deprivation period (first injection) and to maintain high levels of leptin during tests for reinstatement (second injection). At each dose condition, rats were tested for reinstatement under free-feeding conditions and after food deprivation, in a counterbalanced order. Tests were separated 72-96 hr apart, and regular extinction sessions were given on the days between testing.

Experiment 2: effect of leptin on footshock- and heroin priming-induced reinstatement. Twenty-one rats were randomly assigned to one of the three leptin dose conditions: vehicle, $2 \mu \mathrm{g} / \mathrm{rat}$, or $4 \mu \mathrm{g} / \mathrm{rat}(n=7 \mathrm{per}$ dose). Rats were exposed, in a counterbalanced order, to a $15 \mathrm{~min}$ intermittent footshock $(0.6 \mathrm{~mA} ; 0.5 \mathrm{sec} \mathrm{ON}$; a mean OFF period of 40 $\mathrm{sec})$, a heroin priming injection $(0.25 \mathrm{mg} / \mathrm{kg}$, s.c.), and a saline injection (subcutaneous; control condition) just before the test sessions. Tests were done during 3 consecutive daily sessions. Leptin-vehicle injections were given $21 \mathrm{hr}$ before the first test session and 20-30 min before each of the subsequent test sessions. The footshock parameters and the heroinpriming dose were based on previous studies (Shaham et al., 2000a).

\section{RESULTS}

\section{Training and extinction phases}

Rats demonstrated reliable heroin self-administration behavior and a pronounced extinction burst when heroin was removed. The mean number of heroin reinforcements and the total responses on the active (reinforcements plus timeout responses) and the inactive levers in the two experiments during the morning session of the last day of training are shown in Table 1 . This table also shows the mean number of nonreinforced responses on the previously active lever and on the inactive lever in the first and last session of extinction. No significant group differences within each experiment in any of the measures were obtained (data not shown). In addition, no differences were obtained across experiments during the training and extinction phases (Table 1).

\section{Experiment 1: effect of leptin on food deprivation-induced reinstatement}

Because of skewed distributions, a square-root transformation (Cohen and Cohen, 1983) was used before conducting the re- 

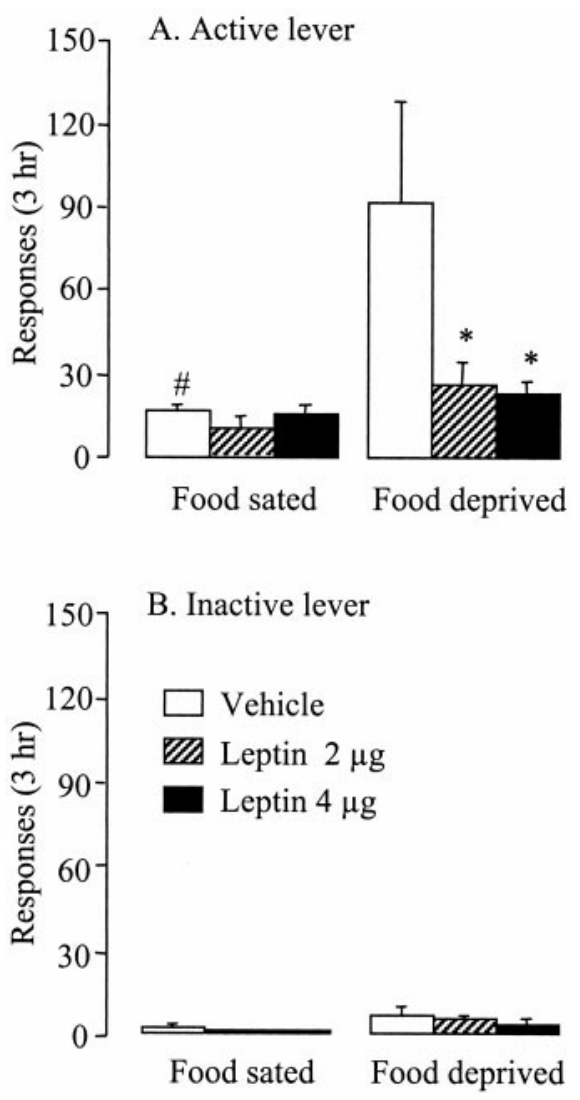

Figure 1. Leptin attenuates acute food deprivation-induced reinstatement of heroin seeking. $A$, Mean \pm SEM number of responses on the previously active lever during tests for reinstatement under the food deprivation $(1 \mathrm{~d})$ and food sated conditions after intracerebroventricular infusions of vehicle (distilled water; $2 \mu \mathrm{l}$ ) or leptin $(2$ or $4 \mu \mathrm{g}$ ). Leptin infusions were given twice: $21 \mathrm{hr}$ and $20-30 \mathrm{~min}$ before the start of the tests for reinstatement. $B$, Mean number of responses on the inactive lever during testing ( $n=8-9$ per dose). ${ }^{*} p<0.01$, different from the vehicle condition. $\# p<0.01$, different from the deprivation condition within each dose condition (Fisher's PLSD post hoc test).

peated measures ANOVA with leptin dose $(0,2$, or $4 \mu \mathrm{g})$ as the between-subjects factor and food deprivation (food deprived and food sated) as the within-subjects factor. Food deprivation increased responding on the previously active lever (a measure of drug seeking), an effect that was significantly attenuated by leptin (Fig. 1A). The statistical analysis revealed significant effects of leptin dose $\left(F_{(2,22)}=4.8 ; p<0.02\right)$, food deprivation $\left(F_{(1,22)}=\right.$ 20.6; $p<0.01)$, and leptin dose by food deprivation $\left(F_{(2,22)}=5.2\right.$; $p<0.02)$. Regardless of the test condition, lever pressing on the inactive lever (a measure of nonspecific activity and/or response generalization) was very low ( $<10$ responses/3 hr) (Fig. $1 B)$, and neither leptin nor food deprivation altered this response $(p$ values $>0.05$ ). Leptin also decreased body weight gain when food was reintroduced after $1 \mathrm{~d}$ of deprivation (vehicle group, $20.6 \pm$ 3.7 gm per day; leptin groups, $7.2 \pm 2.3$; $p<0.01$ ) but had no effect on body weight loss induced by food deprivation (vehicle group, $22.2 \pm 7.7 \mathrm{gm}$ per day; leptin groups, $26.4 \pm 2.1 ; p>0.5)$.

\section{Experiment 2: effect of leptin on footshock- and heroin} priming-induced reinstatement

Because of skewed distributions, a square-root transformation was used. The repeated measures ANOVA using leptin dose $(0$, 2 , or $4 \mu \mathrm{g})$ as the between-subjects factor and test condition
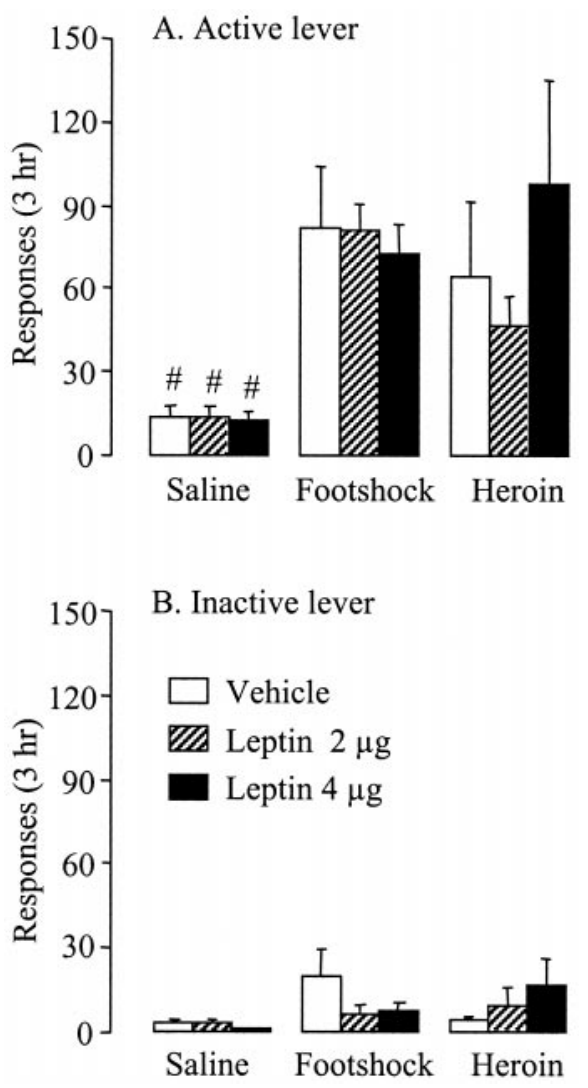

Figure 2. Leptin does not alter footshock stress- and heroin priminginduced reinstatement of heroin seeking. $A$, Mean number of responses on the previously active lever during tests for reinstatement after exposure to saline priming (control condition), heroin priming $(0.25 \mathrm{mg} / \mathrm{kg}$, s.c.), and $15 \mathrm{~min}$ of intermittent footshock after intracerebroventricular infusions of vehicle (distilled water; $2 \mu \mathrm{l}$ ) or leptin $(2$ or $4 \mu \mathrm{g})$. B, Mean number of responses on the inactive lever during testing ( $n=7$ per dose). $\# p<0.01$, different from footshock or heroin priming within each dose condition (Fisher's PLSD post hoc test).

(saline priming, heroin priming, and footshock) as the withinsubjects factor revealed significant effects of test condition on responses on the previously active lever $\left(F_{(2,36)}=12.2 ; p<0.01\right)$ (Fig. $2 A)$ and on the inactive lever $\left(F_{(2,36)}=3.2 ; p<0.05\right)$ (Fig. $2 B)$. Therefore, a change-score analysis was performed on responses on the previously active lever minus responses on the inactive lever. This analysis also revealed a significant test condition $\left(F_{(2,36)}=10.4 ; p<0.01\right)$. Thus, after taking into account nonspecific activity and/or response generalization, both heroin priming and footshock effectively reinstated heroin seeking. These effects, however, were not attenuated by leptin (leptin dose by test condition, $\left.F_{(4,36)}=0.7, \mathrm{NS}\right)$.

\section{DISCUSSION}

The main finding in this report is that reinstatement of heroin seeking induced by acute food deprivation is attenuated by intracerebroventricular infusions of leptin. In contrast, leptin has no effect on reinstatement induced by exposure to intermittent footshock or heroin priming injections. These data indicate that acute food deprivation reinstates heroin seeking via a leptin-dependent mechanism, which does not modulate reinstatement induced by footshock or heroin priming. The present data, and the recent finding that leptin reverses chronic food restriction-induced sensitization of lateral hypothalamus BSR (Fulton et al., 2000), 
suggest that central leptin systems are involved in the changes in motivational states induced by food deprivation or restriction.

\section{Neuronal mechanisms involved in the effect of leptin on food deprivation-induced reinstatement}

The present data indicate that leptin acts centrally to attenuate acute food deprivation-induced reinstatement, and based on previous research, it is likely that hypothalamic sites are involved. Although leptin receptors are expressed in a number of peripheral tissues and brain sites, the hypothalamus is the main site of the actions of leptin (Ahima et al., 2000). Central administration of leptin reduces body weight in rats at doses that are several folds lower than the effective peripheral doses (Campfield et al., 1996). Leptin receptors are localized in hypothalamic areas known to regulate food intake (Elmquist et al., 1998), and mRNA for leptin was found recently in these areas (Wilkinson et al., 2000). Finally, infusions of leptin into the ventromedial hypothalamus, lateral hypothalamus, and arcuate nucleus reduce food intake in rats (Ahima et al., 2000). The present data also raise the possibility that other hypothalamic hormones, which are modulated by leptin, may be involved in acute food deprivation-induced reinstatement of heroin seeking. These include, among others, galanin, agouti-related protein, neuropeptide Y, and cocaine- and amphetamine-regulated transcript (Lawrence et al., 1999).

\section{Implications of the findings to mechanisms underlying relapse to heroin seeking}

It has been shown that heroin priming reinstates heroin seeking by activating neuronal systems that are distinct from those underlying reinstatement induced by footshock stress (Shaham et al., 2000a). Heroin priming is thought to induce reinstatement of heroin seeking by activating the mesolimbic dopaminergic (DA) reward system; morphine infusions into the ventral tegmental area (VTA) or amphetamine infusions into the nucleus accumbens (NAS) mimic the effect of priming injections of heroin, given systemically (Stewart, 1984; Stewart and Vezina, 1988). On the other hand, footshock is thought to induce reinstatement of drug seeking by activating central NA and extrahypothalamic CRF systems, most likely within the amygdala and bed nucleus of stria terminalis (BNST) (Erb and Stewart, 1999; Shaham et al., 2000a). Food deprivation, therefore, can act on leptin-sensitive hypothalamic neurons that in turn may activate brain systems involved in reinstatement induced by footshock (e.g., BNST and amygdala) or heroin priming (e.g., VTA, NAS). Many anatomical and neurophysiological studies demonstrate neuronal connections between the above brain structures and the hypothalamus (Heimer et al., 1997; Pacak et al., 1998; Kelley, 1999).

Thus, to the extent that acute food deprivation induces neurochemical changes similar to those induced by chronic food restriction, as the data on the effect of these conditions on opioid and psychostimulant intravenous self-administration suggest (Carroll, 1999), acute food deprivation may reinstate heroin seeking by its actions on the mesolimbic DA system. Chronic food restriction increases morphine- and cocaine-induced DA release in the NAS and enhances locomotor activity induced by central injections of amphetamine or morphine into the NAS or VTA, respectively (Piazza and Le Moal, 1996, 1998). Food restriction also augments amphetamine-induced c-fos expression in the NAS (Carr and Kutchukhidze, 2000).

On the other hand, acute food deprivation may reinstate heroin seeking by mimicking the actions of footshock on stress-related systems. Acute (24-48 hr) food deprivation increases CRF (Hei- nrichs and Richard, 1999) and NA (Stanley et al., 1989) utilization in the hypothalamus, a region that receives its major NA input from the lateral tegmental NA nuclei via the ventral NA bundle (Moore and Bloom, 1979; Pacak et al., 1998). This neuronal projection has been shown recently to be involved in footshockinduced reinstatement of heroin seeking (Shaham et al., 2000b). The effect of acute food deprivation on extrahypothalamic CRF and NA has not been studied, but these systems also might be activated by this deprivation condition. Acute food deprivation increases neuronal activity, as assessed by c-fos expression, in both hypothalamic and extrahypothalamic (amygdala, BNST, and paraventricular thalamus) sites (Horvath et al., 1999). The fact that some of the activated cells in the extrahypothalamic sites contain CRF makes it possible that acute food deprivation acts on those systems that mediate reinstatement of heroin seeking induced by footshock.

\section{Implications for the treatment of relapse to drug use in humans}

There exist suggestive evidence that food restriction or deprivation increases drug intake and provokes relapse to drug use in humans (Franklin et al., 1948; Hall et al., 1992; Niaura et al., 1992). In addition, it has been suggested (Carr, 1996; Carroll, 1999) that the increase in drug-motivated behavior during food restriction in laboratory animals is of relevance to the understanding of the high comorbidity between eating disorders and substance abuse in humans (Holderness et al., 1994). The present study demonstrates that even short-term fasting can promote drug seeking in heroin-experienced rats and that this effect can be modulated by leptin, a hormone involved in the regulation of energy balance and food intake. Thus, medications that target the central leptin system and/or other hypothalamic hormones that are regulated by leptin (Ahima et al., 2000) may be considered for the treatment of drug addicts with comorbid eating disorders.

\section{REFERENCES}

Ahima RS, Saper CB, Flier JS, Elmquist JK (2000) Leptin regulation of neuroendocrine systems. Front Neuroendocrinol 21:263-307.

Buczek Y, Lê AD, Wang A, Stewart J, Shaham Y (1999) Stress reinstates nicotine seeking but not sucrose solution seeking in rats. Psychopharmacology 144:183-188.

Cabeza de Vaca S, Carr KD (1998) Food restriction enhances the central rewarding effect of abused drugs. J Neurosci 18:7502-7510.

Cabib S, Orsini C, Le Moal M, Piazza PV (2000) Abolition and reversal of strain differences in behavioral responses to drugs of abuse after a brief experience. Science 289:463-465.

Campfield LA, Smith FJ, Burn P (1996) The OB protein (leptin) pathway - a link between adipose tissue mass and central neural networks. Horm Metab Res 28:619-632.

Carr KD (1996) Feeding, drug abuse, and the sensitization of reward by metabolic need. Neurochem Res 21:1455-1467.

Carr KD, Kutchukhidze N (2000) Chronic food restriction increases fos-like immunoreactivity (FLI) induced in rat forebrain by intraventricular amphetamine. Brain Res 861:88-96.

Carr KD, Simon EJ (1984) Potentiation of reward by hunger is opioid mediated. Brain Res 297:369-373.

Carroll ME (1985) The role of food deprivation in the maintenance and reinstatement of cocaine-seeking behavior in rats. Drug Alcohol Depend 16:95-109.

Carroll ME (1999) Interaction between food and addiction. In: Neurobiobehavioral toxicology and addiction: food, drugs and environment (Niesnik RJM, Hoefakker RE, Westera W, Jaspers RMA, Kornet LMW, Boobis S, eds), pp 286-311. Boca Raton, FL: CRC.

Cohen J, Cohen P (1983) Applied multiple regression/correlation analysis for the behavioral sciences, Ed 2. Hillsdale: Erlbaum.

Dallman MF, Akana SF, Bhatnagar S, Bell ME, Choi S, Chu A, Horsley C, Levin N, Meijer O, Soriano LR, Strack AM, Viau V (1999) Starvation: early signals, sensors, and sequelae. Endocrinology 140:4015-4023.

Elmquist JK, Bjorbaek C, Ahima RS, Flier JS, Saper CB (1998) Distributions of leptin receptor mRNA isoforms in the rat brain. J Comp Neurol 395:535-547. 
Erb S, Stewart J (1999) A role for the bed nucleus of the stria terminalis, but not the amygdala, in the effects of corticotropin-releasing factor on stress-induced reinstatement of cocaine seeking. J Neurosci RC35:1-6.

Erb S, Shaham Y, Stewart J (1996) Stress reinstates cocaine-seeking behavior after prolonged extinction and drug-free periods. Psychopharmacology 128:408-412.

Franklin JC, Shiele BC, Brozek J, Keys A (1948) Observations on human behavior in experimental semistarvation and rehabilitation. J Clin Psychol 4:28-45.

Friedman JM, Halaas JL (1998) Leptin and the regulation of body weight in mammals. Nature 395:763-770.

Fulton S, Woodside B, Shizgal P (2000) Modulation of brain reward circuitry by leptin. Science 287:125-128.

Gaiardi M, Bartoletti M, Bacchi A, Gubellini C, Babbini M (1987) Increased sensitivity to the stimulus properties of morphine in food deprived rats. Pharmacol Biochem Behav 26:719-723.

Hall SM, Tunstall CD, Vila KL, Duffy J (1992) Weight gain prevention and smoking cessation: cautionary findings. Am J Public Health 82:799-803.

Heimer L, Harlan RE, Alheid GF, Garcia MM, De Olmos J (1997) Substantia innominata: a notion which impedes clinical-anatomical correlations in neuropsychiatric disorders. Neuroscience 76:957-1006.

Heinrichs SC, Richard D (1999) The role of corticotropin-releasing factor and urocortin in the modulation of ingestive behavior. Neuropeptides 33:350-359.

Holderness CC, Brooks-Gunn J, Warren MP (1994) Co-morbidity of eating disorders and substance abuse review of the literature. Int $\mathrm{J}$ Eat Disord 16:1-34.

Horvath TL, Warden CH, Hajos M, Lombardi A, Goglia F, Diano S (1999) Brain uncoupling protein 2: uncoupled neuronal mitochondria predict thermal synapses in homeostatic centers. J Neurosci 19:10417-10427.

Kelley AE (1999) Functional specificity of ventral striatal compartments in appetitive behaviors. Ann NY Acad Sci 877:71-90.

Lawrence CB, Turnbull AV, Rothwell NJ (1999) Hypothalamic control of feeding. Curr Opin Neurobiol 9:778-783.

Lê AD, Quan B, Juzystch W, Fletcher PJ, Joharchi N, Shaham Y (1998) Reinstatement of alcohol-seeking by priming injections of alcohol and exposure to stress in rats. Psychopharmacology 135:169-174.

Moore RY, Bloom FE (1979) Central catecholaimine neuron systems: anatomy and physiology of the norepinephrine and epinephrine systems. Annu Rev Neurosci 2:113-168.

Niaura R, Clark MM, Raciti MA, Pera V, Abrams DB (1992) Increased saliva cotinine concentrations in smokers during rapid weight loss. J Consult Clin Psychol 60:985-987.

Pacak K, Palkovits M, Kopin IJ, Goldstein DS (1998) Stress-induced norepinephrine release in the hypothalamic paraventricular nucleus and pituitary-adrenocortical and sympathoadrenal activity: in vivo microdialysis studies. Front Neuroendocrinol 16:89-150.

Paxinos G, Watson C (1998) The rat brain in stereotaxic coordinates, Ed 4. San Diego: Academic.

Piazza PV, Le Moal M (1996) Pathophysiological basis of vulnerability to drug abuse: interaction between stress, glucocorticoids, and dopaminergic neurons. Annu Rev Pharmacol Toxicol 36:359-378.

Piazza PV, Le Moal M (1998) The role of stress in drug selfadministration. Trends Pharmacol Sci 19:67-74.

Shaham Y, Stewart J (1995) Stress reinstates heroin self-administration behavior in drug-free animals: an effect mimicking heroin, not withdrawal. Psychopharmacology 119:334-341.

Shaham Y, Erb S, Stewart J (2000a) Stress-induced relapse to heroin and cocaine seeking in rats: a review. Brain Res Rev 33:13-33.

Shaham Y, Highfield D, Delfs JM, Leung S, Stewart J (2000b) Clonidine blocks stress-induced reinstatement of heroin seeking in rats: an effect independent of the locus coeruleus noradrenergic neurons. Eur J Neurosci 12:292-302.

Shalev U, Highfield D, Yap J, Shaham Y (2000) Stress and relapse to drug seeking in rats: studies on the generality of the effect. Psychopharmacology 150:337-346.

Shiffman S, Wills TA (1985) Coping and substance abuse. Orlando, FL: Academic.

Sinha R, Catapano D, O’Mally S (1999) Stress-induced craving and stress responses in cocaine dependent individuals. Psychopharmacology 142:343-351.

Stanley BG, Schwartz DH, Hernandez L, Hoebel BG, Leibowitz SF (1989) Patterns of extracellular norepinephrine in the paraventricular hypothalamus: relationship to circadian rhythm and deprivationinduced eating behavior. Life Sci 45:275-282.

Stewart J (1984) Reinstatement of heroin and cocaine selfadministration behavior in the rat by intracerebral application of morphine in the ventral tegmental area. Pharmacol Biochem Behav 20:917-923.

Stewart J, de Wit H (1987) Reinstatement of drug-taking behavior as a method of assessing incentive motivational properties of drugs. In: Methods of assessing the reinforcing properties of abused drugs (Bozarth MA, ed), pp 211-227. New York: Springer.

Stewart J, Vezina P (1988) A comparison of the effects of intraaccumbens injections of amphetamine and morphine on reinstatement of heroin intravenous self-administration behavior. Brain Res 457:287-294.

Widdowson PS, Upton R, Buckingham R, Arch J, Williams G (1997) Inhibition of food response to intracerebroventricular injection of leptin is attenuated in rats with diet-induced obesity. Diabetes 46:1782-1785.

Wilkinson M, Morash B, Ur E (2000) The brain is a source of leptin. Front Horm Res 26:106-125. 